\title{
The degree of an Internet addiction among school youth
}

\author{
Stopień uzależnienia od Internetu w grupie uczniów szkół gimnazjalnych i licealnych
}

\section{Barbara Niedorys ${ }^{1}$, Monika Mikos ${ }^{1}$, Katarzyna Kocka² , Barbara Ślusarska ${ }^{2}$}

\author{
'absolwentka kierunku Pielęgniarstwo Wydziału Nauk o Zdrowiu Uniwersytetu Medycznego w Lublinie/ \\ a graduate of the Faculty of Health Sciences at the Medical University of Lublin. \\ ${ }^{2}$ Zakład Medycyny Rodzinnej i Pielęgniarstwa Środowiskowego, Wydział Nauk o Zdrowiu, Uniwersytet Medyczny w Lublinie/ \\ Department of Family Medicine and Community Nursing, Faculty of Health Sciences, Medical University of Lublin
}

AUTOR DO KORESPONDENCJI/CORRESPONDING AUTHOR:

Barbara Niedorys

Wydział Nauk o Zdrowiu UM w Lublinie ul. Staszica 4/6, 20-250 Lublin e-mail: baskaniedorys@gmail.com

\section{STRESZCZENIE}

Słowa kluczowe:

\section{ABSTRACT}

Key words:

\section{STOPIEN UZALEZNIENIA OD INTERNETU W GRUPIE UCZNIÓW SZRÓL GIMNAZJALNYCH I LICEALNYCH}

Wprowadzenie. Rozwój mass mediów, w tym Internetu znacząco wpłynął na styl życia współczesnej młodzieży. Pomimo powszechnego dostępu oraz niezliczonych możliwości jakie daje Internet, coraz częstszym zjawiskiem obserwowanym od kilku lat jest nadmierne korzystanie z sieci przez młodzież, które może prowadzić do uzależnienia od Internetu.

Cel pracy. Celem niniejszej pracy było określenie stopnia uzależnienia od Internetu w grupie uczniów szkół gimnazjalnych i licealnych oraz wybranych uwarunkowań tego stanu.

Materiał i metody. W pracy posłużono się metodą sondażu diagnostycznego z wykorzystaniem techniki ankiety. Kwestionariusz pytań zawierał standaryzowany test Kimberly Young oraz ankietę własnego autorstwa. Badania przeprowadzono na grupie 263 uczniów szkół gimnazjalnych i licealnych, w okresie od kwietnia do czerwca 2018r.

Wyniki. Wśród badanych uczniów u blisko 11\% stwierdzono uzależnienie od Internetu. Najczęstszym celem wykorzystywania Internetu przez ankietowanych było korzystanie z serwisów społecznościowych (95\%). Dolegliwościami zdrowotnymi związanymi z długim czasem korzystania z sieci u uczniów uzależnionych było ogólne przemęczenie i niewyspanie (61\%). Osoby uzależnione od Internetu znacznie częściej czuły się samotne (61\%), przygnębione, zdenerwowane lub smutne 78,6\% (n=22) w porównaniu z grupą pozostałych badanych.

Wnioski. Zmienne demograficzne nie mają znaczącego wpływu na rozwój uzależnienia od Internetu. Funkcjonowanie psychospołeczne wpływa na rozwój uzależnienia od Internetu.

uzależnienie, Internet, młodzież szkolna

\section{THE DEGREE OF AN INTERNET ADDICIION AMONG SCHOOL YOUTH}

Introduction. The development of mass media, including an Internet has a significant impact on the lifestyle of young people. Despite of universal access and countless opportunities offered via Internet, an increasingly common phenomenon observed for several years is the excessive use of networks by young people, which can lead to Internet addiction.

Aim. The aim of this study was to determine the degree of the Internet addiction in a group of junior high school students and high school students and selected conditions of this state.

Material and methods. The applied research method was a diagnostic survey, and the following tools: the Kimberly Young's Internet Addiction Test and the authors' self-designed survey. The study covered 263 junior high school and high school students. The research was carried out from April to June 2018.

Results. The Internet addiction was observed in $11 \%$ of the surveyed students. The use of social networking sites was the most common reason for using the Internet among surveyed (95\%). The health problems associated with the long time of using the network of addicted students were general fatigue (61\%) and lack of sleep (61\%). Students addicted to the Internet much more often felt lonely (61\%), depressed, upset or sad $(n=22,78.6 \%)$ in contrast to other respondents.

Conclusions. Demographic variables (such as: sex, type of school, place of residence) have no significant impact on the development of Internet addiction. Psychosocial functioning has an impact on the development of the Internet addiction. 


\section{INTRODUCTION}

Nowadays, the young people are characterised by a specific use of media, mainly Internet, that is why they are often called „the Google generation”. This is due to the fact that youth do not know the world without a computer or a smartphone. Many times the students use audiobooks or online materials instead of books, while a Google search has become an alternative to a library or reading room [1]. The network determines the functioning of the young generation and the Internet accompanies young people everytime and everywhere. The Internet is treated by youth as something natural and necessary and its lack is unbelievable [2]. Therefore, there are often abuses leading to excessive use of the Internet, what creates the risk of addiction.

\section{AIM}

The aim of this study was to determine the degree of the Internet addiction in a group of junior high school and high school students and selected conditions of this state.

\section{MATERIALS AND METHODS}

The applied research method was a diagnostic survey. The research tool was a standardized Kimberly Young's Internet Addiction Test assessing the degree of the Internet addiction. The questionnaire consists of 8 statements to which the examined person answers: YES or NO. The sum of responses allows to determine the appropriate level of the Internet addiction. In addition, the research used an authors' self-designed questionnaire including 4 questions concerning demographic characteristic of the respondents, 14 questions related to psychosocial functioning and 11 questions related to Internet behavior.

The research was carried out from April to June 2018 in schools in Lublin, Łaszczów and Nabróż. The participation in the study was voluntary and anonymous. The approval of the Bioethical Commission No. KE-0254/93/2018 was obtained for conducting these research.

StatSoft Statistica $13 \mathrm{PL}$ and Microsoft Office package were used for statistical analysis. Interrelation between the groups were determined by the Pearson Chi square test, Mann-Whitney U test and Kruskal - Wallis test, accepted at $\mathrm{p}<0.05$.

\section{RESULTS}

Among the respondents $(n=263)$ there were $52 \%$ of junior high school students and $48 \%$ of high school students. Nearly $75 \%$ of all the students were girls and $25 \%$ were boys. Almost $41 \%$ of students were inhabitants of cities, while $59 \%$ of them came from the countryside. The average age of respondents was $15.4( \pm 1.4)$ years.

The Kimberly Young's Internet Addiction Test showed that $10.6 \%$ of respondents were addicted to the Internet and $7.2 \%$ of them have the risk of the Internet addiction. The Internet addiction was twice as often among junior high school students (13.9\%) than in high school students (7.1\%). Similarly, rural residents were more often addicted to the Internet than inhabitants of cities (12.9\% vs. $7.4 \%)$.

The risk of the Internet addiction has occurred in $7.2 \%$ of students. This group consisted of $12.1 \%$ boys and $5.6 \%$ girls $-7.1 \%$ high school students and $7.3 \%$ junior high school students. Almost twice as many people at risk of Internet addiction came from the cities than from the countryside ( $10.2 \%$ vs. $5.2 \%$ ).

The sex, type of school and place of residence were not statistically significant with addiction to the Internet ( $p>0.05$ ). The exact results of the research are presented in the Table 1

The use of social networking sites, like Facebook, Instagram, Snapchat, etc., was the most common reason for using the Internet. This was indicated by $85.7 \%(n=24)$ of students addicted to the Internet and by all students from the risk group $(100 \%, n=19)$. Equally often students used the Internet to study. This answer was chosen by $57.1 \%(n=16)$ of students addicted to the Internet, more than half $(52.6 \%, \mathrm{n}=10)$ respondents at risk of addiction and $70.8 \%(n=153)$ of those non - addicted. Another purpose of using the Internet among the surveyed were listening to songs and watching movies. Nearly $57.1 \%$ $(n=6)$ of students addicted to the Internet, $68.4 \%(n=13)$ of respondents from the risk group and $67.1 \%(n=145)$ of non - addicted persons indicated these answer. Students addicted to the Internet used Internet chat $(28.6 \%)$ or made online purchases $(21.4 \%)$ more often than another respondents. The exact results of this research are presented in the Table 2.

The health problems associated with the long time of using the network among $60.7 \%(n=17)$ of students addicted to the Internet were general fatigue and lack of

Tab. 1. Demographic characteristics and the Kimberly Young's Internet Addiction Test

\begin{tabular}{|c|c|c|c|c|c|c|c|c|}
\hline \multirow{2}{*}{\multicolumn{2}{|c|}{$\begin{array}{l}\text { Young's test } \\
\text { Level of addiction }\end{array}$}} & \multirow{3}{*}{$\begin{array}{c}\text { Together } \\
216 \\
\end{array}$} & \multicolumn{2}{|c|}{ Sex } & \multicolumn{2}{|c|}{ School } & \multicolumn{2}{|c|}{ Place of residence } \\
\hline & & & \multirow{2}{*}{$\begin{array}{c}\text { Male } \\
50 \\
\end{array}$} & \multirow{2}{*}{$\frac{\text { Female }}{166}$} & \multirow{2}{*}{$\begin{array}{c}\text { Junior high school } \\
108 \\
\end{array}$} & \multirow{2}{*}{$\begin{array}{c}\text { High school } \\
108 \\
\end{array}$} & \multirow{2}{*}{$\begin{array}{c}\text { City } \\
89 \\
\end{array}$} & \multirow{2}{*}{$\begin{array}{c}\text { Countryside } \\
127\end{array}$} \\
\hline No addiction & $\mathrm{n}$ & & & & & & & \\
\hline ( $\leq 3 \mathrm{pts})$ & $\%$ & $82.1 \%$ & $75.8 \%$ & $84.3 \%$ & $78.8 \%$ & $85.7 \%$ & $82.4 \%$ & $81.9 \%$ \\
\hline \multirow{2}{*}{$\begin{array}{l}\text { Risk } \\
\text { (4 pts) }\end{array}$} & $\mathrm{n}$ & 19 & 8 & 11 & 10 & 9 & 11 & 8 \\
\hline & $\%$ & $7.2 \%$ & $12.1 \%$ & $5.6 \%$ & $7.3 \%$ & $7.1 \%$ & $10.2 \%$ & $5.2 \%$ \\
\hline \multirow{2}{*}{$\begin{array}{l}\text { Internet Addiction } \\
\text { ( } \geq 5 \mathrm{pts})\end{array}$} & $\mathrm{n}$ & 28 & 8 & 20 & 19 & 9 & 8 & 20 \\
\hline & $\%$ & $10.6 \%$ & $12.1 \%$ & $10.2 \%$ & $13.9 \%$ & $7.1 \%$ & $7.4 \%$ & $12.9 \%$ \\
\hline Altogether & $\mathrm{n}$ & 263 & 66 & 197 & 137 & 126 & 108 & 155 \\
\hline \multicolumn{2}{|l|}{ Stat. Chi^2," ${ }^{\prime \prime}$} & - & \multicolumn{2}{|c|}{$p=0.17031$} & \multicolumn{2}{|c|}{$p=0.20500$} & \multicolumn{2}{|c|}{$p=0.13324$} \\
\hline
\end{tabular}


sleep. The similar answer was chosen by $52.6 \%(n=10)$ of respondents at risk of addiction. Another frequent health problem that occurred in $53.6 \%(n=15)$ of students addicted to the Internet and in $52.6 \%(\mathrm{n}=10)$ of respondents at risk of addiction were vision disorders, such as impaired vision, burning or tearing eyes. Students addicted to the Internet reported difficulty in concentrating $(42.9 \%$, $\mathrm{n}=12)$ more often than those at risk of addiction $(26.3 \%$,

- Tab. 2. The scopes and purposes of using the Internet

\begin{tabular}{|c|c|c|c|c|c|}
\hline \multirow{2}{*}{\multicolumn{2}{|c|}{$\begin{array}{l}\text { For what purposes do } \\
\text { you use the Internet? }\end{array}$}} & \multirow{3}{*}{$\begin{array}{c}\text { Together } \\
53 \\
\end{array}$} & \multicolumn{3}{|c|}{ Young's test } \\
\hline & & & \multirow{2}{*}{$\begin{array}{c}\begin{array}{c}\text { No } \\
\text { addiction }\end{array} \\
43 \\
\end{array}$} & \multirow{2}{*}{$\begin{array}{c}\text { Risk } \\
5 \\
\end{array}$} & \multirow{2}{*}{$\begin{array}{c}\text { Internet } \\
\text { Addiction } \\
5\end{array}$} \\
\hline \multirow{2}{*}{ on - line games } & $\mathrm{n}$ & & & & \\
\hline & $\% *$ & $20.2 \%$ & $19.9 \%$ & $26.3 \%$ & $17.9 \%$ \\
\hline \multirow{2}{*}{$\begin{array}{l}\text { using of social } \\
\text { networking sites }\end{array}$} & $\mathrm{n}$ & 249 & 206 & 19 & 24 \\
\hline & $\% *$ & $94.7 \%$ & $95.4 \%$ & $100.0 \%$ & $85.7 \%$ \\
\hline \multirow{2}{*}{ studying } & $n$ & 179 & 153 & 10 & 16 \\
\hline & $\%^{*}$ & $68.1 \%$ & $70.8 \%$ & $52.6 \%$ & $57.1 \%$ \\
\hline \multirow{2}{*}{ Internet chat } & $\mathrm{n}$ & 52 & 40 & 4 & 8 \\
\hline & $\%^{*}$ & $19.8 \%$ & $18.5 \%$ & $21.1 \%$ & $28.6 \%$ \\
\hline \multirow{2}{*}{$\begin{array}{l}\text { downloading files } \\
\text { (movies, music) }\end{array}$} & $n$ & 73 & 58 & 9 & 6 \\
\hline & $\%^{*}$ & $27.8 \%$ & $26.9 \%$ & $47.4 \%$ & $21.4 \%$ \\
\hline \multirow{2}{*}{$\begin{array}{l}\text { listening to songs, } \\
\text { watching movies }\end{array}$} & $\mathrm{n}$ & 174 & 145 & 13 & 16 \\
\hline & $\%^{*}$ & $66.2 \%$ & $67.1 \%$ & $68.4 \%$ & $57.1 \%$ \\
\hline \multirow{2}{*}{$\begin{array}{l}\text { making online } \\
\text { purchases }\end{array}$} & $n$ & 44 & 36 & 2 & 6 \\
\hline & $\%^{*}$ & $16.7 \%$ & $16.7 \%$ & $10.5 \%$ & $21.4 \%$ \\
\hline $\begin{array}{l}\text { Number of } \\
\text { respondents }\end{array}$ & $n$ & 263 & 216 & 19 & 28 \\
\hline
\end{tabular}

* multiple choice question, does not add up to $100 \%$

Tab. 3. The health problems associated with the long time of using the Internet

\begin{tabular}{|c|c|c|c|c|c|}
\hline \multirow{2}{*}{\multicolumn{2}{|c|}{$\begin{array}{l}\text { Do you have any } \\
\text { health problems } \\
\text { listed below? }\end{array}$}} & \multirow{3}{*}{$\begin{array}{c}\text { Together } \\
105\end{array}$} & \multicolumn{3}{|c|}{ Young's test } \\
\hline & & & \multirow{2}{*}{$\begin{array}{c}\text { No } \\
\text { addiction }\end{array}$} & \multirow{2}{*}{$\begin{array}{c}\text { Risk } \\
10\end{array}$} & \multirow{2}{*}{$\begin{array}{c}\begin{array}{c}\text { Internet } \\
\text { Addiction }\end{array} \\
15\end{array}$} \\
\hline \multirow{2}{*}{ vision disorders } & $\mathrm{n}$ & & & & \\
\hline & $\% *$ & $39.9 \%$ & $37.0 \%$ & $52.6 \%$ & $53.6 \%$ \\
\hline \multirow{2}{*}{$\begin{array}{l}\text { hearing } \\
\text { impairment }\end{array}$} & $n$ & 18 & 9 & 3 & 6 \\
\hline & $\% *$ & $6.8 \%$ & $4.2 \%$ & $15.8 \%$ & $21.4 \%$ \\
\hline \multirow{2}{*}{ spine pain } & $\mathrm{n}$ & 64 & 48 & 7 & 9 \\
\hline & $\% *$ & $24.3 \%$ & $22.2 \%$ & $36.8 \%$ & $32.1 \%$ \\
\hline \multirow{2}{*}{$\begin{array}{l}\text { general fatigue } \\
\text { and lack of sleep }\end{array}$} & $n$ & 125 & 98 & 10 & 17 \\
\hline & \%* & $47.5 \%$ & $45.4 \%$ & $52.6 \%$ & $60.7 \%$ \\
\hline \multirow{2}{*}{$\begin{array}{l}\text { difficulty in } \\
\text { concentrating }\end{array}$} & $\mathrm{n}$ & 56 & 39 & 5 & 12 \\
\hline & $\% *$ & $21.3 \%$ & $18.1 \%$ & $26.3 \%$ & $42.9 \%$ \\
\hline \multirow{2}{*}{$\begin{array}{l}\text { frequent } \\
\text { headaches }\end{array}$} & $n$ & 83 & 71 & 4 & 8 \\
\hline & $\% *$ & $31.6 \%$ & $32.9 \%$ & $21.1 \%$ & $28.6 \%$ \\
\hline \multirow{2}{*}{$\begin{array}{l}\text { wrist pain, hand } \\
\text { tingling }\end{array}$} & $\mathrm{n}$ & 22 & 16 & 3 & 3 \\
\hline & $\% *$ & $8.4 \%$ & $7.4 \%$ & $15.8 \%$ & $10.7 \%$ \\
\hline \multirow{2}{*}{$\begin{array}{l}\text { irritability, } \\
\text { nervousness }\end{array}$} & $n$ & 69 & 52 & 7 & 10 \\
\hline & \%* & $26.2 \%$ & $24.1 \%$ & $36.8 \%$ & $35.7 \%$ \\
\hline $\begin{array}{l}\text { Number of } \\
\text { respondents }\end{array}$ & $\mathrm{n}$ & 263 & 216 & 19 & 28 \\
\hline
\end{tabular}

* multiple choice question, does not add up to $100 \%$ $\mathrm{n}=5)$ and non - addicted respondents $(18.1 \%, \mathrm{n}=39)$. In contrast, frequent headaches were indicated by $32.9 \%$ $(n=71)$ of students non - addicted to the Internet, $28.6 \%$ $(n=8)$ of surveyed addicted to the Internet and $21.1 \%$ $(n=4)$ of respondents at risk of addiction. The exact results are presented in the Table 3.

Frequent sense of loneliness was twice as often among students addicted to the Internet $(60.7 \%, \mathrm{n}=17)$ than in those non - addicted $(30.6 \%, n=66)$. Frequent feeling of depression, nervousness or sadness were indicated by more than half of students addicted to the Internet $(78.6 \%$, $\mathrm{n}=22)$. The similar answer was chosen by $57.9 \%(\mathrm{n}=11)$ of respondents at risk of addiction and $36.1 \%(n=78)$ of non - addicted respondents. The exact results of this research are presented in the Table 4.

\section{DISCUSSION}

The Internet accompanies young people everytime and everywhere, provides quick access to information, develops knowledge and interests, opens up new horizons and hides innumerable possibilities. It is an alternative to spending free time [3]. However the boundary between the rational use of the network and the abuse of this benefit is very thin.

The presented research showed that the problem of the Internet addiction occurs in $10.6 \%$ of respondents and $7.2 \%$ of all surveyed are at the risk group of addiction. According to CBOS research [4] from 2015, 6.2\% of students aged 15-17 are at risk group or have a problem with Internet addiction. In the Pawłowska and Potembska's studies [5] carried out on a group of 129 high school students (boys), the risk of Internet addiction was found among $34.2 \%$ of all students. Nearly $66 \%$ of high school students were not endangered with addiction. In other studies of these authors [6], which included 206 high school students, 113 junior high school students and 200 students

Tab. 4. Psychosocial functioning and the Kimberly Young's Internet Addiction Test

\begin{tabular}{|c|c|c|c|c|c|}
\hline \multirow{2}{*}{\multicolumn{2}{|c|}{$\begin{array}{l}\text { For what purposes do } \\
\text { you use the Internet? }\end{array}$}} & \multirow{3}{*}{$\begin{array}{c}\text { Together } \\
87\end{array}$} & \multicolumn{3}{|c|}{ Young's test } \\
\hline & & & \multirow{2}{*}{$\begin{array}{c}\begin{array}{c}\text { No } \\
\text { addiction }\end{array} \\
66\end{array}$} & \multirow{2}{*}{$\begin{array}{c}\text { Risk } \\
4\end{array}$} & \multirow{2}{*}{$\begin{array}{c}\begin{array}{c}\text { Internet } \\
\text { Addiction }\end{array} \\
17\end{array}$} \\
\hline \multirow{2}{*}{ yes } & $\mathrm{n}$ & & & & \\
\hline & $\%$ & $33.1 \%$ & $30.6 \%$ & $21.1 \%$ & $60.7 \%$ \\
\hline \multirow{2}{*}{ no } & $n$ & 176 & 150 & 15 & 11 \\
\hline & $\%$ & $66.9 \%$ & $69.4 \%$ & $78.9 \%$ & $39.3 \%$ \\
\hline altogether & $\mathrm{n}$ & 263 & 216 & 19 & 28 \\
\hline \multicolumn{2}{|c|}{ Stat. Chi $\wedge 2, "{ }^{\prime \prime}$} & - & \multicolumn{3}{|c|}{$p=0,00315$} \\
\hline \multirow{2}{*}{\multicolumn{2}{|c|}{$\begin{array}{l}\text { For what purposes do } \\
\text { you use the Internet? }\end{array}$}} & \multirow[b]{2}{*}{ Together } & \multicolumn{3}{|c|}{ Young's test } \\
\hline & & & $\begin{array}{c}\text { No } \\
\text { addiction }\end{array}$ & Risk & $\begin{array}{l}\text { Internet } \\
\text { Addiction }\end{array}$ \\
\hline \multirow{2}{*}{ yes } & $\mathrm{n}$ & 111 & 78 & 11 & 22 \\
\hline & $\%$ & $42.2 \%$ & $36.1 \%$ & $57.9 \%$ & $78.6 \%$ \\
\hline \multirow{2}{*}{ no } & $n$ & 152 & 138 & 8 & 6 \\
\hline & $\%$ & $57.8 \%$ & $63.9 \%$ & $42.1 \%$ & $21.4 \%$ \\
\hline altogether & $\mathrm{n}$ & 263 & 216 & 19 & 28 \\
\hline \multicolumn{2}{|c|}{ Stat. Chi $\wedge 2, " p "$} & & \multicolumn{3}{|c|}{$D=0.00004$} \\
\hline
\end{tabular}


of higher education, the following results were obtained: 3.5 of surveyed were addicted to the Internet (6\% were boys) and $34 \%$ of respondents were in a risk group - more often they were male persons (57\%). In Białkoz - Kalinowska et al. studies [7] carried out on 102 high school students, almost $20 \%$ of respondents were at risk of Internet addiction. Among this risk group there were 30\% of boys $(n=17)$ and $9 \%$ of girls. Moreover, the author did not find people addicted from the Internet among the studied students.

In the Dębska et al. studies [8] carried out on 127 high school students, including $67 \%$ boys and $33 \%$ girls, nearly $19 \%$ of respondents ( $14 \%$ boys and $33 \%$ girls) were in a group with the risk of Internet addiction, while $2 \%$ of the surveyed boys had a problem with Internet addiction. In Toranto et al. studies [9] carried out on a group of 402 high school students, including 191 boys and 211 girls, $4.7 \%$ of respondents were addicted to the Internet. In all of the above studies $[5,6,8]$, boys were addicted to the Internet more often than girls. A similar results were also obtained in own research, but these were not statistically significant values.

The above results may be significantly influenced by the fact that the surveyed junior high school students were in the so-called rebellion period. It is the time of great changes both hormonal, physical and mental, which lead to determine their own identity. For teenagers, the Internet becomes a convenient way to get rid of fear and aggression which accompany them during adolescence. Furthermore, risky behaviors that occur among young people result in a large number of students addicted to the Internet.

In the subject literature, there are often descriptions of the negative impact of the Internet on health $[10,11]$. This fact relates mainly to the physical dimension of health. Internet abuse may cause serious health problems, such as: defects of posture, visual impairment or nerves palsy, which are responsible for wrists' and hands' movements [8]. In Białkoz - Kalinowska et al. studies [7], the most frequent health problem associated with long-term use of the Internet were headaches and back pains - almost $35 \%$ of respondents reported this inconvenience. Another health problems were: eye pains and worsening visual acuity $-32 \%$, tension of the neck, shoulder and shoulders - 25\%, pain or stiffness of the wrist - $4 \%$. In Dębska et al. studies [8], nearly $57 \%$ of boys and $47 \%$ of girls declared eye pains accompanying the long-term use of the Internet, while headaches were on the second place (36\% of boys and $18 \%$ of girls). About $12 \%$ of the surveyed (only girls) complained of backache caused by inappropriate posture at the computer, while fatigue was reported by $7 \%$ of boys and $23 \%$ of girls. Slightly different results were obtained in own research, where the most frequent health problem associated with long-term use of the Internet, reported by $60.7 \%$ of students addicted to the Internet and $52.6 \%$ of respondents at risk of addiction were general fatigue and lack of sleep. Almost $53 \%$ of students addicted to the Internet and $52.6 \%$ of those in the risk group declared that they have vision disorders. Frequent headaches were more often indicated by students who were not addicted to the
Internet in comparison to the addicted group (32.9\% vs. $28.6 \%$ ). Moreover, wrist pain and tingling of the hand was accompanied by $10.7 \%$ of students addicted to the Internet and $15.8 \%$ respondents of the risk group. Additionally, difficulties with attention were an important problem, which were reported by $42.9 \%$ of surveyed with Internet addiction and by $26.3 \%$ of those at risk of addiction.

An important issue in the sphere of the psycho-social functioning of young people is the sense of value or low mood, which can significantly affect the development of Internet addiction [12-16]. Janocha et al. [17] claimed that long - staying in the network may lead to depression as women are more often exposed to depressive disorders associated with the Internet addiction than men. The own research showed that nearly $60.7 \%$ of students addicted to the Internet declared that they often feel lonely. About $64.3 \%$ of Internet-addicted respondents and $42.1 \%$ students of risk group admitted that they felt like they are less worth than others. Low self-esteem was more often reported by girls than boys ( $35.5 \%$ vs. $27.3 \%$ ). Nearly $79 \%$ of students addicted to the Internet and $57.9 \%$ those at risk of addiction submitted feeling depressed, upset or sad. Similarly to the above, this problem more often affected girls than boys ( $44.3 \%$ vs. $36.4 \%$ ).

The phenomenon of Internet addiction is a growing problem, which affects mainly school teenagers. The Internet replaced meetings with friends, fun in the yard, a good book, and even time that we could spend with family. It is a great blessing of the 21 st century, but unskillfully dosed, it can become a curse of modern man. It is important to remember that the degree to which the Internet will take control over our lives depends only on us. Therefore, parents, caregivers, teachers as well as school nurses should pay attention to youth's behaviour in order to diagnose the problem of Internet addiction as soon as possible and take appropriate actions to eliminate it.

\section{CONCLUSIONS}

- Demographic variables (such as: sex, type of school, place of residence) have no significant impact on the development of Internet addiction.

- There are many health problems accompanied with Internet addiction. The most frequent are: general fatigue, lack of sleep, vision disorders (like amblyopia, tearing, burning eyes), difficulties with concentration, irritability and nervousness.

- The most common reason for using Internet by school youth are maintaining interpersonal contacts in social networks (like Facebook, Instagram), studying and listening to music or watching movies.

- Psychosocial functioning has an impact on the development of Internet addiction. The problem of Internet addiction more often affects people with a sense of loneliness, depression and sadness. 


\section{Stopień uzależnienia od Internetu w grupie uczniów szkół gimnazjalnych i licealnych}

\section{WPROWADZENIE}

Współczesnych adolescentów charakteryzuje specyficzny sposób korzystania z mediów, w tym głownie z Internetu dlatego często nazywani są pokoleniem „kopiuj - wklej” lub „Google generation”. Takie opisywanie młodzieży ma swoje odbicie w fakcie, iż nie znają oni świata bez komputera czy smartfona. Uczniowie często zamiast po książki sięgają po audiobooki czy materiały online, zaś alternatywą biblioteki czy czytelni stała się dla nich wyszukiwarka Google [1]. Sieć internetowa determinuje środowisko funkcjonowania młodego pokolenia. Internet młodemu człowiekowi towarzyszy zawsze i wszędzie. Młodzież traktuje Internet w sposób naturalny i niezbędny do prawidłowego funkcjonowania, a jego brak jest czymś niewyobrażalnym [2]. W związku z tym często dochodzi do nadużyć prowadzących do nadmiernego użytkowania Internetu, co stwarza ryzyko uzależnienia.

\section{CEL PRACY}

Celem niniejszej pracy było określenie stopnia uzależnienia od Internetu w grupie uczniów szkół gimnazjalnych i licealnych oraz wybranych uwarunkowań tego stanu.

\section{MATERIAŁ I METODY}

Badania przeprowadzono metodą sondażu diagnostycznego z wykorzystaniem techniki ankiety. Narzędziem badawczym był standaryzowany test dr Kimberly Young, oceniający stopień uzależnienia od Internetu. Kwestionariusz składa się z 8 stwierdzeń, na które osoba badana odpowiada TAK lub NIE. Suma poszczególnych odpowiedzi pozwala odnieść wyniki do odpowiedniego stopnia uzależnienia. Ponadto w badaniach wykorzystano autorski kwestionariusz ankiety, składający się z 4 pytań dotyczących danych demograficznych, 14 pytań odnoszących się do funkcjonowania psychospołecz- nego oraz 11 pytań dotyczących zachowań związanych $\mathrm{z}$ Internetem. Badania przeprowadzono w okresie od kwietnia do czerwca 2018r. w szkołach w Lublinie, Łaszczowie i Nabrożu. Przystąpienie do badania było całkowicie dobrowolne i anonimowe. Na przeprowadzenie niniejszych badań uzyskano zgodę Komisji Bioetycznej nr KE-0254/93/2018.

Analizę statystyczną wyników wykonano za pomoca pakietu StatSoft Statistica 13 PL oraz przy udziale pakietu Microsoft Office, przy wykorzystaniu testu Chi Kwadrat Pearsona, U Manna-Whitneya i Kruskala-Wallisa. Przyjęto, iż $\mathrm{p}<0,05$ wskazuje na występowanie związku istotnego statystycznie.

\section{WYNIKI}

Wśród respondentów $(\mathrm{n}=263$ ) 52\% stanowili uczniowie gimnazjum, zaś $48 \%$ liceum. Prawie $75 \%$ badanych stanowiły dziewczęta, zaś $25 \%$ chłopcy. Blisko $41 \%$ uczniów było mieszkańcami miast, natomiast $59 \%$ pochodziło ze wsi. Średnia wieku respondentów wynosiła 15,4 $( \pm 1,4)$ lat.

Test dr Kimberly Young wykazał, że 10,6\% badanych było uzależnionych od Internetu, zaś u 7,2\% występowało ryzyko uzależnienia. Dwukrotnie częściej uzależnienie od sieci występowało wśród uczniów gimnazjum $(13,9 \%)$ niż liceum $(7,1 \%)$. Podobnie częściej uzależnieni od Internetu byli mieszkańcy wsi niż miast (12,9\% vs $7,4 \%)$.

Ryzyko uzależnienia od Internetu wystapiło u 7,2\% uczniów. W grupie tej znalazło się 12,1\% chłopców oraz 5,6\% dziewcząt oraz 7,1\% licealistów i 7,3\% uczniów gimnazjum. Prawie dwa razy więcej osób z grupy ryzyka uzależnienia od Internetu pochodziło z miasta niż ze wsi (10,2\% vs $5,2 \%)$

Nie wykazano istotnych zależności statystycznych pomiędzy wynikami testu uzależnienia od Internetu a płcią, rodzajem szkoły i miejscem zamieszkania ( $p>0,05)$. Dokładne wyniki badań obrazuje Tabela 1 .

Tab. 1. Wyniki testu uzależnienia od Internetu wg dr K. Young oraz ich związek z wybranymi cechami społeczno-demograficznymi

\begin{tabular}{|c|c|c|c|c|c|c|c|c|}
\hline \multirow{2}{*}{\begin{tabular}{|c|}
$\begin{array}{c}\text { Test uzależneinia } \\
\text { od Internetu } \\
\text { dr Kimberly Young }\end{array}$ \\
\end{tabular}} & & \multirow{2}{*}{ Razem } & \multicolumn{2}{|c|}{ Płeć } & \multicolumn{2}{|c|}{ Szkoła } & \multicolumn{2}{|c|}{ Miejsce zamieszkania } \\
\hline & & & Mężczyzna & Kobieta & Gimnazjum & Liceum & Miasto & Wieś \\
\hline \multirow{2}{*}{$\begin{array}{l}\text { Brak uzależnienia } \\
\text { ( } \leq 3 \mathrm{pts} \text { ) }\end{array}$} & $\mathrm{n}$ & 216 & 50 & 166 & 108 & 108 & 89 & 127 \\
\hline & $\%$ & $82.1 \%$ & $75.8 \%$ & $84.3 \%$ & $78.8 \%$ & $85.7 \%$ & $82.4 \%$ & $81.9 \%$ \\
\hline \multirow{2}{*}{$\begin{array}{l}\text { Ryzyko uzależnienia } \\
\text { (4 pts) }\end{array}$} & $\mathrm{n}$ & 19 & 8 & 11 & 10 & 9 & 11 & 8 \\
\hline & $\%$ & $7.2 \%$ & $12.1 \%$ & $5.6 \%$ & $7.3 \%$ & $7.1 \%$ & $10.2 \%$ & $5.2 \%$ \\
\hline \multirow{2}{*}{$\begin{array}{l}\text { Uzależnienie od Internetu } \\
\text { ( } \geq 5 \text { pts) }\end{array}$} & $\mathrm{n}$ & 28 & 8 & 20 & 19 & 9 & 8 & 20 \\
\hline & $\%$ & $10.6 \%$ & $12.1 \%$ & $10.2 \%$ & $13.9 \%$ & $7.1 \%$ & $7.4 \%$ & $12.9 \%$ \\
\hline Ogółem & $n$ & 263 & 66 & 197 & 137 & 126 & 108 & 155 \\
\hline \multicolumn{2}{|l|}{ Stat. Chi $\wedge 2, " p "$} & - & \multicolumn{2}{|c|}{$p=0,17031$} & \multicolumn{2}{|c|}{$p=0,20500$} & \multicolumn{2}{|c|}{$p=0,13324$} \\
\hline
\end{tabular}


Najczęściej wymienianym celem korzystania z Internetu przez ankietowanych było korzystanie z serwisów społecznościowych tj. Facebook, Instagram, Snapchat itp. Na tą czynność wskazało $85,7 \%(n=24)$ osób uzależnionych od Internetu, oraz wszyscy badani z grupy ryzyka $(100 \%, n=19)$. Równie często uczniowie wykorzystywali Internet do nauki. Odpowiedź tą wybrało 57,1\% $(\mathrm{n}=16)$ osób uzależnionych, oraz ponad połowa $(52,6 \%$, $\mathrm{n}=10)$ z grupy ryzyka oraz $70,8 \%(\mathrm{n}=153)$ uczniów nieuzależnionych od Internetu. Słuchanie utworów muzycznych i oglądanie filmów było kolejnym dość popularnym celem korzystania z sieci wśród respondentów. Na te czynności wskazało $57,1 \%(\mathrm{n}=6)$ osób $\mathrm{z}$ grupy uzależnionych od Internetu, $68,4 \%(\mathrm{n}=13)$ zagrożonych uzależnieniem oraz $67,1 \%(n=145)$ uczniów nieuzależnionych od Internetu. Osoby z uzależnieniem od Internetu częściej korzystały z czatów internetowych $(28,6 \%)$ czy dokonywały zakupów on-line $(21,4 \%)$ niż inne grupy ankietowanych. Szczegółowe wyniki badań na ten temat przedstawia Tabela 2.

Dolegliwościami zdrowotnymi związanymi z długotrwałym korzystaniem $\mathrm{z}$ sieci u uczniów uzależnionych od Internetu w $60,7 \%(n=17)$ było ogólne przemęczenie i niewyspanie. Podobnej odpowiedzi udzieliło 52,6\% $(n=10)$ uczniów z grupy ryzyka uzależnienia. Kolejną częstą dolegliwością, na którą wskazało 53,6\% (n=15) uczniów uzależnionych od Internetu i 52,6\% $(n=10)$ z grupy ryzyka były zaburzenia narządu wzroku w postaci niedowidzenia, pieczenia czy łzawienia oczu. Uczniowie uzależnieni od Internetu częściej zgłaszali trudności z koncentracją uwagi $(42,9 \%, \mathrm{n}=12) \mathrm{w}$ porównaniu do grupy osób $\mathrm{z}$ istniejącym ryzykiem uzależnienia $(26,3 \%, n=5)$ oraz bez problemu uzależnienia od Internetu $(18,1 \%, \mathrm{n}=39)$. Natomiast na częste bóle głowy wskazało aż 32,9\% (n=71) osób nieuzależnionych od Internetu, 28,6\% ( $\mathrm{n}=8$ ) uczniów uzależnionych i $21,1 \%(n=4)$ z grupy ryzyka uzależnienia od Internetu. Dokładne wyniki zawiera Tabela 3.

- Tab. 2. Zakresy i cele korzystania z Internetu

\begin{tabular}{|l|c|c|c|c|c|}
\hline \multicolumn{2}{|c|}{$\begin{array}{c}\text { Do jakich celów } \\
\text { wykorzystujesz } \\
\text { Internet? }\end{array}$} & \multirow{2}{*}{ Razem } & \multicolumn{3}{c|}{ Wynik testu dr Young } \\
\cline { 3 - 6 } & & $\begin{array}{c}\text { Brak } \\
\text { uzależnienia }\end{array}$ & Ryzyko & $\begin{array}{c}\text { Uzależnienie } \\
\text { od Internetu }\end{array}$ \\
\hline \multirow{2}{*}{ gry on-line } & $\mathrm{n}$ & 53 & 43 & 5 & 5 \\
\cline { 2 - 6 } & $\%^{*}$ & $20.2 \%$ & $19.9 \%$ & $26.3 \%$ & $17.9 \%$ \\
\hline $\begin{array}{l}\text { korzystanie } \\
\text { z serwisów } \\
\text { społecznościowych }\end{array}$ & $\mathrm{n}$ & 249 & 206 & 19 & 24 \\
\cline { 2 - 6 } & $\%^{*}$ & $94.7 \%$ & $95.4 \%$ & $100.0 \%$ & $85.7 \%$ \\
\hline \multirow{2}{*}{ do nauki } & $\mathrm{n}$ & 179 & 153 & 10 & 16 \\
\cline { 2 - 6 } & $\%^{*}$ & $68.1 \%$ & $70.8 \%$ & $52.6 \%$ & $57.1 \%$ \\
\hline \multirow{2}{*}{$\begin{array}{l}\text { czaty } \\
\text { internetowe }\end{array}$} & $\mathrm{n}$ & 52 & 40 & 4 & 8 \\
\cline { 2 - 6 } & $\%^{*}$ & $19.8 \%$ & $18.5 \%$ & $21.1 \%$ & $28.6 \%$ \\
\hline \multirow{2}{*}{$\begin{array}{c}\text { ściąganie plików } \\
\text { (filmy, muzyka) }\end{array}$} & $\mathrm{n}$ & 73 & 58 & 9 & 6 \\
\cline { 2 - 6 } & $\%^{*}$ & $27.8 \%$ & $26.9 \%$ & $47.4 \%$ & $21.4 \%$ \\
\hline \multirow{2}{*}{$\begin{array}{l}\text { słuchanie muzyki } \\
\text { i oglądanie filmów }\end{array}$} & $\mathrm{n}$ & 174 & 145 & 13 & 16 \\
\cline { 2 - 6 } & $\%^{*}$ & $66.2 \%$ & $67.1 \%$ & $68.4 \%$ & $57.1 \%$ \\
\hline $\begin{array}{l}\text { dokonywanie } \\
\text { zakupów }\end{array}$ & $\mathrm{n}$ & 44 & 36 & 2 & 6 \\
\cline { 2 - 6 } & $\%^{*}$ & $16.7 \%$ & $16.7 \%$ & $10.5 \%$ & $21.4 \%$ \\
\hline $\begin{array}{l}\text { Liczb } \\
\text { odpowiadajacych }\end{array}$ & $\mathrm{n}$ & 263 & 216 & 19 & 28 \\
\hline \multirow{2}{*}{$*$}
\end{tabular}

* nie sumuje się do 100\% ze względu na możliwość wyboru kilku odpowiedzi
Dwa razy więcej uczniów uzależnionych od Internetu $(60,7 \%, n=17)$ zgłaszało częste poczucie osamotnienia $w$ stosunku do uczniów nieuzależnionych $(30,6 \%, \mathrm{n}=66)$. Najwięcej uczniów z grupy uzależnionych wskazywało na częste uczucie przygnębienia, zdenerwowania lub smutku $(78,6 \%, n=22)$. Podobnej odpowiedzi udzieliło $57,9 \%$ $(n=11)$ respondentów z grupy ryzyka uzależnienia i 36,1\% $(n=78)$ osób nieuzależnionych od Internetu. Szczegółowe dane na ten temat przedstawia Tabela 4.

Tab. 3. Dolegliwości zdrowotne związane z nadmiernym korzystaniem z Internetu

\begin{tabular}{|c|c|c|c|c|c|}
\hline \multirow{2}{*}{\multicolumn{2}{|c|}{$\begin{array}{l}\text { Czy występuje u Ciebie } \\
\text { któraś z podanych } \\
\text { poniżej dolegliwości? }\end{array}$}} & \multirow{3}{*}{$\begin{array}{c}\text { Razem } \\
105\end{array}$} & \multicolumn{3}{|c|}{ Wynik testu dr Young } \\
\hline & & & \multirow{2}{*}{$\begin{array}{c}\begin{array}{c}\text { Brak } \\
\text { uzależnienia }\end{array} \\
80\end{array}$} & \multirow{2}{*}{\begin{tabular}{|c|} 
Ryzyko \\
10
\end{tabular}} & \multirow{2}{*}{$\begin{array}{c}\begin{array}{c}\text { Uzależnienie } \\
\text { od Internetu }\end{array} \\
15\end{array}$} \\
\hline \multirow{2}{*}{$\begin{array}{l}\text { zaburzenia } \\
\text { wzroku }\end{array}$} & $n$ & & & & \\
\hline & $\%^{*}$ & $39.9 \%$ & $37.0 \%$ & $52.6 \%$ & $53.6 \%$ \\
\hline \multirow{2}{*}{$\begin{array}{l}\text { zaburzenia } \\
\text { słuchu }\end{array}$} & $n$ & 18 & 9 & 3 & 6 \\
\hline & $\%^{*}$ & $6.8 \%$ & $4.2 \%$ & $15.8 \%$ & $21.4 \%$ \\
\hline \multirow{2}{*}{$\begin{array}{l}\text { dolegliwości } \\
\text { bólowe kręgosłupa }\end{array}$} & $\mathrm{n}$ & 64 & 48 & 7 & 9 \\
\hline & $\%^{*}$ & $24.3 \%$ & $22.2 \%$ & $36.8 \%$ & $32.1 \%$ \\
\hline \multirow{2}{*}{$\begin{array}{l}\text { ogólne } \\
\text { przemęczenie } \\
\text { i niewyspanie }\end{array}$} & $n$ & 125 & 98 & 10 & 17 \\
\hline & $\%^{*}$ & $47.5 \%$ & $45.4 \%$ & $52.6 \%$ & $60.7 \%$ \\
\hline \multirow{2}{*}{$\begin{array}{l}\text { trudności z } \\
\text { koncentracją } \\
\text { uwagi }\end{array}$} & $\mathrm{n}$ & 56 & 39 & 5 & 12 \\
\hline & $\%^{*}$ & $21.3 \%$ & $18.1 \%$ & $26.3 \%$ & $42.9 \%$ \\
\hline \multirow{2}{*}{$\begin{array}{l}\text { częste } \\
\text { bóle głowy }\end{array}$} & $\mathrm{n}$ & 83 & 71 & 4 & 8 \\
\hline & $\%^{*}$ & $31.6 \%$ & $32.9 \%$ & $21.1 \%$ & $28.6 \%$ \\
\hline \multirow{2}{*}{$\begin{array}{l}\text { bóle nadgarstka, } \\
\text { mrowienie dłoni }\end{array}$} & $\mathrm{n}$ & 22 & 16 & 3 & 3 \\
\hline & $\%^{*}$ & $8.4 \%$ & $7.4 \%$ & $15.8 \%$ & $10.7 \%$ \\
\hline \multirow{2}{*}{$\begin{array}{l}\text { rozdrażnienie, } \\
\text { zdenerwowanie }\end{array}$} & $n$ & 69 & 52 & 7 & 10 \\
\hline & $\%^{*}$ & $26.2 \%$ & $24.1 \%$ & $36.8 \%$ & $35.7 \%$ \\
\hline $\begin{array}{l}\text { Liczb } \\
\text { odpowiadajacych }\end{array}$ & $\mathrm{n}$ & 263 & 216 & 19 & 28 \\
\hline
\end{tabular}

* nie sumuje się do 100\% ze względu na możliwość wyboru kilku odpowiedzi

Tab. 4. Funkcjonowanie psychiczne a uzależnienie od Internetu

\begin{tabular}{|c|c|c|c|c|c|}
\hline \multirow{2}{*}{\multicolumn{2}{|c|}{$\begin{array}{l}\text { Czy często czujesz się } \\
\text { samotny/a? }\end{array}$}} & \multirow{3}{*}{$\begin{array}{c}\text { Razem } \\
87\end{array}$} & \multicolumn{3}{|c|}{ Wynik testu dr Young } \\
\hline & & & \multirow{2}{*}{\begin{tabular}{|c|}
$\begin{array}{c}\text { Brak } \\
\text { uzależnienia }\end{array}$ \\
66
\end{tabular}} & \multirow{2}{*}{$\begin{array}{c}\text { Ryzyko } \\
4\end{array}$} & \multirow{2}{*}{$\begin{array}{c}\begin{array}{c}\text { Uzależnienie } \\
\text { od Internetu }\end{array} \\
17\end{array}$} \\
\hline \multirow{2}{*}{ tak } & $n$ & & & & \\
\hline & $\%$ & $33.1 \%$ & $30.6 \%$ & $21.1 \%$ & $60.7 \%$ \\
\hline \multirow{2}{*}{ nie } & $n$ & 176 & 150 & 15 & 11 \\
\hline & $\%$ & $66.9 \%$ & $69.4 \%$ & $78.9 \%$ & $39.3 \%$ \\
\hline Ogółem & $n$ & 263 & 216 & 19 & 28 \\
\hline \multicolumn{2}{|c|}{ Stat. Chi^2," $p "$} & - & \multicolumn{3}{|c|}{$p=0,00315$} \\
\hline \multirow{2}{*}{\multicolumn{2}{|c|}{$\begin{array}{l}\text { Czy często jesteś } \\
\text { przygnębiony, } \\
\text { zdenerwowany } \\
\text { lub smutny? }\end{array}$}} & \multirow[b]{2}{*}{ Razem } & \multicolumn{3}{|c|}{ Wynik testu dr Young } \\
\hline & & & $\begin{array}{c}\text { Brak } \\
\text { uzależnienia }\end{array}$ & Ryzyko & $\begin{array}{l}\text { Uzależnienie } \\
\text { od Internetu }\end{array}$ \\
\hline \multirow{2}{*}{ tak } & $n$ & 111 & 78 & 11 & 22 \\
\hline & $\%$ & $42.2 \%$ & $36.1 \%$ & $57.9 \%$ & $78.6 \%$ \\
\hline \multirow{2}{*}{ nie } & $\mathrm{n}$ & 152 & 138 & 8 & 6 \\
\hline & $\%$ & $57.8 \%$ & $63.9 \%$ & $42.1 \%$ & $21.4 \%$ \\
\hline Ogółem & $\mathrm{n}$ & 263 & 216 & 19 & 28 \\
\hline \multicolumn{2}{|c|}{ Stat. Chi^2," $p^{\prime \prime}$} & & \multicolumn{3}{|c|}{$p=0,00004$} \\
\hline
\end{tabular}




\section{DYSKUSJA}

Internet młodemu człowiekowi towarzyszy zawsze i wszędzie, zapewnia szybki dostęp do informacji, rozwija wiedzę i zainteresowania, otwiera nowe horyzonty i kryje w sobie niezliczoną ilość możliwości. Stanowi alternatywę spędzania wolnego czasu [3]. Warto jednak zauważyć, że granica między racjonalnym korzystaniem $\mathrm{z}$ sieci, a nadużywaniem tego dobrodziejstwa jest bardzo cienka.

W badaniach własnych wykazano, że z problem uzależnienia od Internetu dotyka aż 10,6\% respondentów, zaś $7,2 \%$ znajduje się w grupie ryzyka. Według badań CBOS [4] z 2015 r, aż 6,2\% uczniów w wieku 15-17 lat jest zagrożona lub ma problem $\mathrm{z}$ uzależnieniem od Internetu. W badaniach Pawłowskiej i Potembskiej [5] przeprowadzonych na 129 uczniach liceum (chłopcy), ryzyko uzależnienia od Internetu stwierdzono u 34,2\% uczniów. Niezagrożonych uzależnieniem było 65,8\% licealistów. $\mathrm{W}$ innych badaniach tych autorek [6], przeprowadzonych na 206 uczniach liceum, 113 uczniach gimnazjum i 200 studentach otrzymano nastepujace wyniki: 3,5\% badanych było uzależnionych od Internetu (w tym $6 \%$ stanowili chłopcy), zaś $34 \%$ znalazło się w grupie ryzyka uzależnienia od Internetu, częściej były to osoby płci męskiej (57\%). Białkoz - Kalinowska i wsp. [7] do grupy ryzyka uzależnienia od Internetu zakwalifikowali aż 20\% $(n=21)$ badanej młodzieży licealnej $(n=102)$. Wśród grupy ryzyka uzależnienia, aż 30\% stanowili chłopcy $(n=17)$, a 9\% dziewczęta. Autorka nie stwierdziła wśród uczniów osób uzależnionych od Internetu. Dębska i wsp. [8] przebadali 127 uczniów liceum, w tym 67\% chłopców i 33\% dziewcząt. Wyniki badań powyższych autorów wykazały, że blisko 19\% uczniów w tym 14\% chłopców i 5\% dziewcząt, znajduje się w grupie ryzyka uzależnienia od Internetu, zaś około $2 \%$ jest uzależnionych, przy czym grupę tą stanowili sami chłopcy. Toranto i wsp. [9] przeprowadzili badania na grupie 402 uczniów szkoły średniej, w tym 191 osób stanowili chłopcy i 211 dziewczęta. Wykazano, że $4,7 \%$ spełniało kryteria diagnostyczne dla uzależnienia od Internetu. Jak donoszą wyniki powyższych badań $[5 ; 6 ; 8]$, częściej zagrożeni uzależnieniem od Internetu są chłopcy niż dziewczęta. Podobne wyniki otrzymano również w badaniach własnych, nie były to jednak wartości istotne statystycznie.

Na powyższe wyniki znacząco może wpływać fakt, iż badana młodzież gimnazjalna znajdowała się w okresie tzw. buntu młodzieńczego. To czas wielkich przemian zarówno hormonalnych, fizycznych jak i psychicznych, mających na celu określenie swojej tożsamości. Internet dla nastolatków staje się więc wygodnym sposobem za pośrednictwem, którego mogą kreować swoją tożsamość, wyładowywać agresję i lęk, towarzyszący im w okresie dojrzewania. Wiąże się to $\mathrm{z}$ występowaniem zachowań ryzykownych, co w pewnym stopniu tłumaczy tak dużą ilość uczniów nadużywających i uzależnionych od Internetu.

W literaturze przedmiotu często spotyka się opisy negatywnego wpływu Internetu na zdrowie [10;11]. Często fakt ten dotyczy fizycznego wymiaru zdrowia. Nadużywanie Internetu może wywołać poważne problemy zdrowotne tj. wady postawy, zaburzenia wzroku czy porażenia nerwów odpowiedzialnych za ruchy nadgarstka i dłoni [8]. W badaniach Białkoz - Kalinowskiej i wsp. [7] najczęstszą dolegliwością zdrowotną spowodowaną długim przebywaniem w sieci, zgłaszaną przez uczniów były bóle głowy i pleców - 35\%. Na kolejnym miejscu znalazły się bóle oczu, pogorszenie ostrości widzenia - 32\%, napięcie szyi, barku i łopatek - 25\%, ból lub sztywność nadgarstka - 4\%. U Dębskiej i wsp. [8] do najczęściej wymienianych dolegliwości spowodowanych zbyt długim korzystaniem z Internetu ankietowani zaliczali ból oczu - 57\% chłopców i 47\% dziewcząt. Kolejnym problemem zdrowotnym okazał się ból głowy (36\% chłopców i 18\% dziewcząt). Na bóle pleców spowodowane nieodpowiednią pozycją zajmowaną przy komputerze uskarżały się wyłącznie dziewczęta (12\%), zaś na zmęczenie - 7\% chłopców i $23 \%$ dziewcząt. Nieco inne wyniki uzyskano w badaniach własnych. Tutaj, aż 60,7\% uzależnionych od Internetu i 52,6\% osób z grupy ryzyka uzależnienia zgłosiło jako częsty problem ogólne przemęczenie i niewyspanie. Aż 53\% uczniów uzależnionych i 52,6\% z grupy ryzyka zadeklarowało, że występują u nich zaburzenia narządu wzroku. $\mathrm{Na}$ częste bóle głowy wskazywali częściej uczniowie, u których nie stwierdzono nadużywania Internetu w porównaniu do grupy uzależnionych (32,9\% vs $28,6 \%)$. Natomiast bóle nadgarstka i mrowienie dłoni towarzyszyło $10,7 \%$ osób uzależnionych i $15,8 \%$ z grupy ryzyka. Istotnym problemem zgłaszanym przez $42,9 \%$ uzależnionych i $26,3 \%$ osób z grupy ryzyka były trudności z koncentracją uwagi.

Kolejnym ważnym zagadnieniem w sferze funkcjonowania psycho-społecznego młodych ludzi jest poczucie wartości, czy występowanie obniżonego nastroju, które znacząco mogą wpływać na rozwój uzależnienia od Internetu $[12 ; 13 ; 14 ; 15 ; 16]$. Jak wynika $\mathrm{z}$ badań Janochy i wsp. [17] wielogodzinne przebywanie $\mathrm{w}$ sieci może prowadzić do depresji. Uwagę zwrócono również na fakt, iż to kobiety częściej narażone są na zaburzenia depresyjne związane z nadużywaniem Internetu niż mężczyźni. W badaniach własnych, aż 60,7\% spośród osób uzależnionych zadeklarowało, że często czuje się samotnym. Poczucie, że jest się gorszym od innych towarzyszyło $64,3 \%$ uczniów uzależnionych od Internetu i $42,1 \%$ z grupy ryzyka uzależnienia. Niska samoocena towarzyszyła częściej dziewczętom niż chłopcom (35,5\% vs. $27,3 \%)$ Natomiast poczucie przygnębienia, zdenerwowania lub smutku zgłosiło aż 78,6\% osób uzależnionych od Internetu i 57,9\% uczniów zagrożonych uzależnieniem. Podobnie jak wyżej, częściej problem ten dotyczył dziewcząt niż chłopców (44,3\% vs. $36,4 \%)$

Zjawisko uzależnienia od Internetu stanowi coraz większy problem, na który w szczególnym stopniu narażona jest młodzież w okresie szkolnym. Internet wypiera spotkania z przyjaciółmi, zabawę na podwórku, dobrą książkę, a nawet czas, który moglibyśmy poświęcić najbliższym. Stanowi wielkie dobrodziejstwo XXI wieku lecz nieumiejętnie dawkowany, może stać się przekleństwem współczesnego człowieka. To od nas zależy w jakim stopniu pozwolimy, by Internet przejął kontrolę nad naszym życiem. Kluczem do zachowania równowagi jest zdrowy rozsądek i mądrzy opiekunowie, nauczyciele, a także 
pielęgniarki środowiska nauczania i wychowania, mające kontakt $\mathrm{z}$ uczniem. To właśnie wymienione osoby powinny jako pierwsze zdiagnozować problem nadużywania Internetu i podjąć właściwe działania zmierzające do jego eliminacji.

\section{WNIOSKI}

1. Płeć, rodzaj szkoły oraz miejsce zamieszkania nie mają znaczącego związku z rozwojem uzależnienia od Internetu.

2. Badani wskazują na szereg dolegliwości zdrowotnych związanych ze stopniem uzależnienia od Internetu, spośród których najczęstsze to: ogólne przemęczenie i niewyspanie, zaburzenia narządu wzroku (np. niedowidzenie, łzawienie, pieczenie oczu), trudności z koncentracją uwagi oraz rozdrażnienie i zdenerwowanie.

3. Badana młodzież najczęściej korzysta Internetu w zakresie utrzymywania kontaktów interpersonalnych w portalach społecznościowych (np. Facebook, Instagram), pomocy w nauce oraz słuchania muzyki i oglądania filmów.

4. Stwierdzono związek funkcjonowania psychospołecznego ze stopniem uzależnienia od Internetu. Problem uzależnienia częściej dotykał osób z poczuciem osamotnienia, przygnębienia i smutku.

\section{PIŚMIENNICTWO/REFERENCES}

1. Makaruk K. Korzystanie z portali społecznościowych przez młodzież. Wyniki badania EU NET ADB. Dziecko krzywdzone. Teoria, badania, praktyka. 2013; 12(1): 69-79.

2. Morbitzer J. 0 istocie medialności młodego pokolenia. Neodedigmata. 2011-2012; 33/34: 132- 153.

3. Pawłowska B, Pabis B. Czynniki osobowościowe i rodzinne w uzależnieniu młodzieży od Internetu: opis przypadku. Postępy Psychiatrii i Neurologii. 2007; 1(21): 65-71.

4. Komunikat z badań CBOS. Pracoholicy, siecioholicy, hazardziści... Uzależnienia od zachowań. Nr 76/2015. Warszawa; 2015.

5. Pawłowska B. Potembska E. Uzależnienie od Internetu u uczniów szkół średnich w kontekście czynników rodzinnych. Family Medicine \& Primary Care Review. 2011; 13: 226-228.

6. Pawłowska B, Potembska E. Objawy zagrożenia i uzależnienia od Internetu mierzonego Kwestionariuszem do Badania Uzależnienia od Internetu, autorstwa Pawłowskiej i Potembskiej u młodzieży polskiej w wieku od 13 do 24 lat. Current Problems of Psychiatry. 2011; 12(4): 439-442.

7. Białokoz-Kalinowska I, i wsp. Internet addiction (netaholics) in the secondary school adolescents - impact on the health and psychosocial skills. Pediatria i Medycyna Rodzinna. 2011; 7(4): 372-377.

8. Dębska G, i wsp. Problem używania Internetu przez młodzież. [w:] Zagrożenia zdrowotne wśród dzieci i młodzieży. T. 3. (red.) Seń M, Dębska G. Kraków: Oficyna Wydawnicza AFM; 2011, s. 125-137.

9. Toranto F, i wsp. Zespół uzależnienia od Internetu w grupie 402 uczniów szkoły średniej. Psychiatria Polska. 2015; 49: 255- 263.

10. Caban R, i wsp. Internet and the effects on family relationships. [w:] Internet szanse i zagrożenia. (red.) Czarnecki E, i wsp. Płock: Wydawnictwo Państwowej Wyższej Szkoły Zawodowej w Płocku; 2011, s. 105-109.

11. Chwaszcz J, i wsp. Media. Uzależnienia, fakty i mity. Lublin: Gaudium; 2005.

12. Fundacja Dzieci Niczyje: Nadmierne korzystanie z komputera i Internetu przez dzieci i młodzież. Warszawa: Polskie Centrum Programu Safer Internet; 2012.

13. Jakubik A. Zespół uzależnienia od Internetu. Studia Psychologica. 2002; 3: 133-142.

14. Jarczyńska J, Orzechowska A. Siecioholizm i fonoholizm zagrożeniem współczesnej młodzieży. [w:] Uzależnienia behawioralne i zachowania problemowe młodzieży. (red.) Jarczyńska J. Bydgoszcz: Wydawnictwo Uniwersytetu Kazimierza Wielkiego; 2014, s.121-146.

15. Kaliszewska K. Nadmierne używanie Internetu. Poznań: Wydawnictwo Naukowe UAM; 2007.

16. Makaruk K, Wójcik S. Nadużywanie internetu przez młodzież. Wyniki badania EU NET ADB. Dziecko krzywdzone. Teoria, badania, praktyka. 2013;12(1): 35-48.

17. Janocha A, Klimatskaya LG. Internet Addiction Disorder in pupils and students of Krasnoyarsk (Russia) and Wrocław (Poland). Hygeia Public Health. 2011; 46(4): 449452.

Praca zgłoszona do czasopisma/Manuscript received: 01.06.2018

Praca zaakceptowana do druku/Manuscript accepted: 07.08.2018

Tłumaczenie/Translation: Monika Mikos 